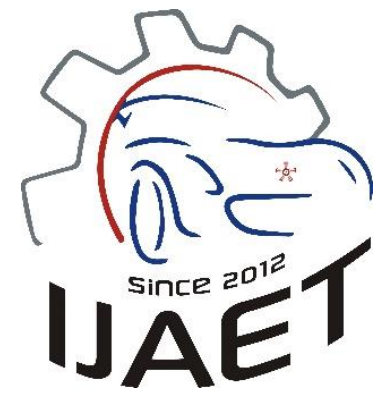

e-ISSN: 2146 - 9067

International Journal of Automotive

Engineering and Technologies

journal homepage:

https://dergipark.org.tr/en/pub/ijaet

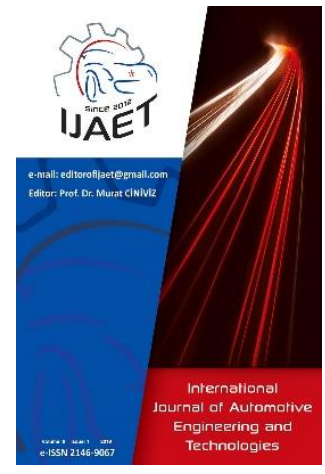

Original Research Article

\title{
Effects on lubricating oil and piston rings of the different operating parameters in a DI diesel engine
}

\author{
İker Temizer ${ }^{1}$ and Ömer Cihan²,*
}

${ }^{1}$,Department of automotive engineering, Technology Faculty, Sivas Cumhuriyet University, 58140, Sivas, Turkey. ${ }^{2}$ Department of mechanical engineering, Engineering Faculty, Hakkari University, 30000, Hakkari, Turkey.

\section{ARTICLE INFO}

${ }^{1} 0000-0003-1170-3898$

${ }^{2} 0000-0001-8103-3063$

* Corresponding author omercihan@hakkari.edu.tr

Received: Oct 28, 2019

Accepted: Mar 10, 2020

Published by Editorial Board Members of IJAET

(C) This article is distributed by Turk Journal Park System under the CC 4.0 terms and conditions.

\begin{abstract}
Biodiesel is an alternative fuel that can be produced from renewable sources such as vegetable and animal fats. It is available as fuel in diesel engines. Also, biodiesel fuel is a type of environmentally friendly fuel that is non-toxic, not perishable in nature. A single cylinder, four-stroke, aircooled, direct-injection diesel engine was used in the study. In the engine is used as fuel of diesel fuel and 10\%, COME (Canola Oil Methyl Ester) was added to diesel fuel.

The piston rings between the engine parts are critical in term of leakage and lubrication. The fuel used affects engine performance and emissions as well as the surface structure of the piston rings. In this study, Antor 3LD510 diesel engine was run with $10 \%$ canola oil methyl ester blended fuel and the engine carried out subjected to long term 150 hours' endurance test. The engine was operated at $1500 \mathrm{rpm}$ and under part load. SEM (Scanning Electron Microscope) and EDX (Energy Dispersive Spectrometry) analysis of the first, second and third piston rings were performed. As a result, after the operation of the engine with both fuels, the $\mathrm{Cr}$ element was largely determined on the surface of the first piston ring and the structure was not disturbed. When the second piston ring surface distribution of COME10 fuel compared to diesel fuel is examined, it is seen that besides the wear elements, combustion and fuel chemistry in the engine are more effective on the surface. The surface of the third piston ring was found to be close to each other after the operating of engine.
\end{abstract}

Keywords: Piston ring; Canola oil methyl ester; Diesel; SEM; EDX; Diesel engine

\section{Introduction}

Nowadays, many researchers are focused on the impact of biodiesel fuels on engine performance and emissions [1-3]. However, lubrication oil and wear behaviors should be examined with the use of biodiesel fuels in reciprocating engines. One of the biggest factors that causes engine oil deterioration is that the soot particles formed as a result of partial combustion in the engine are mixed into the engine oil between the cylinder liner and piston rings. As a result of this process, 
an increase in the viscosity of the engine oil occurs, which affects the performance of the oil. It starts to age as long as each oil is used according to the environment in which it is located, the degree of oil and operating conditions. When the oil ages, its chemical composition and function change [4]. In particular, the residual accumulation behaviors of fuels on engine parts, their effects on lubrication oil and the resulting symptoms of adhesive wear should be extensively evaluated. In some studies, fuel, combustion and lubrication oil deterioration has been extensively monitored and a number of evaluations have been presented [5]. With the increase in the concentration of waste oil in the mixture, it has been reported that reduced viscosity of the lubricant, and there is not much change in the moisture content up to $10 \%$ of the waste oil in the mixture oil [6].

In internal combustion engines, friction losses vary according to engine operating conditions in the most general form. The gains to be obtained in the piston ring-cylinder region where the most wear occurs in the engines will cause a reduction in mechanical losses in the engines and a reduction in fuel consumption. Therefore, the piston rings used today must be selected from materials that are resistant to engine pressure and temperature, but also have high wear resistance on their surfaces [7-8]. In another study, the effect of biodiesel fuels on engine parts and wear behavior were examined. On engine parts subjected to long-term endurance testing, more carbon deposits and engine wear were observed in biodiesel fuels compared to diesel fuel, especially in injectors and combustion chambers. However, it is emphasized that all these negativity is within the limits permitted for the engine [9].

Aging of oil reduces lubrication performance. Transferring oil to contact surfaces at a certain pressure and temperature is of great importance for slowing down the development of friction and wear [10].

Due to differences in the chemical composition of biodiesel and diesel fuels, there show some differences between lubricating oil degradation and useful life. Dhar and Agerwal [11] examined the effect of $20 \%$ karanja biodiesel/diesel mixture on engine tribology at a 200-hour endurance test. Kinematic viscosity, flash point, total alkaline number were less observed in the biodiesel blended engine. Also, density, ash content, moisture content, pentane and benzene values were higher found in the engine using biodiesel fuel.

Pandey and Nandgaonkar conducted in study, as a result of the use of karanja biodiesel, it has been observed that the engine performance has increased as well as low emission values. The engine has been subjected to a 100-hour endurance test. After a 20-hour study, lubrication oil from the engine was subjected to elemental analysis, and metallic residue concentration analysis was performed by using AAS (Atomic Absorber Spectroscopy). It has been determined that metal wear is approximately $30 \%$ lower as a result of the engine operating with biodiesel fuel. Biodiesel fuel, which has higher viscosity compared to diesel fuel, it is stated that the moving parts cause less wear due to the additional lubrication feature [12].

In a study on engine lubricating oil and engine parts, biodiesel fuel mixed (20\% proportion) and mineral diesel fuels were used separately in the engine for 256 hours. In the study, it is stated that more wear elements are formed in the lubricating oil of the engine used biodiesel mixed compared to diesel fuel [13].

However, in many studies, it was emphasized that less wear elements were found in the lubricating oil of the engine used biodiesel fuel and had a positive effect on engine wear of biodiesel fuels [14-16].

Gulzar et al. [17] conducted 200-hour long-term tests to reveal the effects of biodiesel mixtures on lubricating oil and piston. When the results were examined, it was observed that there was a decrease in viscosity and increase in the acidity level in the engine used biodiesel mixed fuel.

Kalam et al. [18] examined the effects on wear and lubrication properties of vegetable oil as fuel. With the fuels used at different rates, the engine was run at a speed of $2000 \mathrm{rpm}$ for 100 hours. The properties of lubricating oil as viscosity, total base number (TBN), moisture content, oxidation, corrosive metals and pollutant were observed.

Gökalp et al. [19] analyzed the wear values of engine with the oil analysis program. Experimental studies have shown that the wearrelated damages that may occur within the 
engine can be predicted with regular oil analyzes.

Balc1 [20] used biodiesel, diesel and bioethanol fuels in a single cylinder diesel engine. In the 100-hour engine trials for each of them, samples from the engine lubricating oil were taken for different periods and the wear element (Al, Fe, $\mathrm{Pb}, \mathrm{Cu}, \mathrm{Cr}$ ) analyzed. When the engine lubricating oil was evaluated, it obtained the best result from E-B3-M3 named mixture fuel. Aydin [21], the effects on lubricating oil of fuels contain different proportions of alcohol, biodiesel and diesel (E2.5-B2.5-M95; E5-B5M90; E5-B2.5-M92.5 and E2.5-B5-M92.5) investigated. The engine was worked 100 hours for each fuel under partial load and took samples from the engine oil at certain hours. When the test results are examined, it is emphasized that the most suitable fuel in terms of the engine performance is M100 and for emissions and lubricating oil it is E2.5-B5-M92.5 fuel.

In this study, Antor 3 LD 510 single cylinder, four-stroke and direct injection a diesel engine was used. The engine was operated with a mixture of $10 \%$ canola oil methyl ester $+90 \%$ diesel fuel (COME10) and diesel fuel. The engine was subjected to a life test by operating with both fuels along 150 hours at $1500 \mathrm{rpm}$ and part load. Within the scope of the study, the surface morphology of the first, second and third piston rings on the piston for both fuels was evaluated the surface structure of the engine before and after the operation. In addition to the tribological properties of the engine parts, it was studied in some physical and chemical properties of the engine lubricating oil under different operating conditions. Thus, both the change in lubricating oil and the effects on engine parts of an engine operating with different fuels were evaluated the changes before and after the study.

\section{Materials and Methods}

\subsection{Experimental study}

In experiments, $10 \%$ by volume of canola oil methyl ester (COME10) was added to diesel fuel. Diesel fuel, which was accepted as a reference, consists of diesel (D100) fuel sold as Euro-diesel in the market. D100 and COME10 test fuels had been used along approximately 150 hours for endurance tests in single-cylinder, direct injection Antor 3LD510 engine. The engine was run for long-term endurance test at $1500 \mathrm{rpm}$ and part load. In Figure 1 was shown the engine and loading unit used in the experiments. Also, in Table 1 was given the technical specifications of the experimental engine. The fuel characteristics of COME and D100 are given in Table 2.

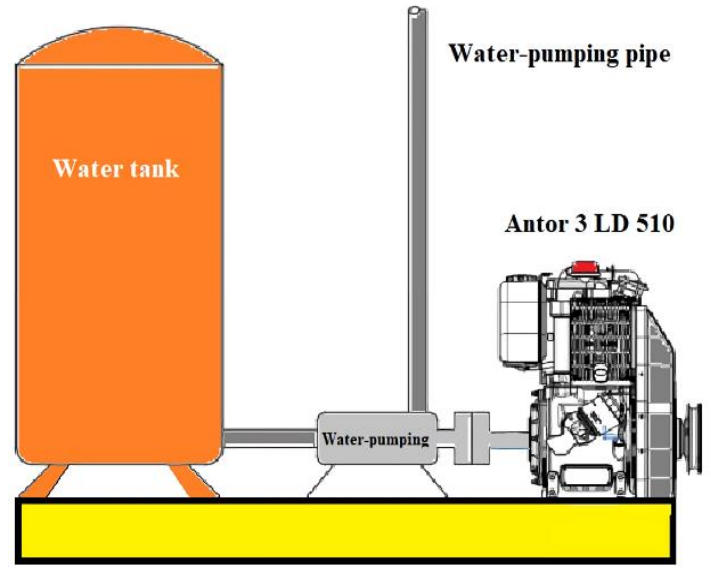

Figure 1. Experimental setup.

Table 1. Technical properties of the test engine

\begin{tabular}{lc}
\hline Specifications & Descriptions \\
\hline Engine type & 4-stroke, direct injection \\
diesel engine
\end{tabular}

Table 2. Characteristic properties of COME and D100 [22]

\begin{tabular}{lll}
\hline Property (Units) & Diesel (D100) & COME \\
\hline $\begin{array}{l}\text { Density }\left(\mathrm{g} / \mathrm{cm}^{3}\right) \\
\text { Kinematic } \\
\left(\mathrm{mm}^{2} / \mathrm{s}, 40{ }^{\circ} \mathrm{C}\right)\end{array}$ & 0.83 & 0.88 \\
Pour point $\left({ }^{\circ} \mathrm{C}\right)$ & 2.75 & 4.7 \\
Flash point $\left({ }^{\circ} \mathrm{C}\right)$ & -12 & -9 \\
Acid value $(\mathrm{mg} \mathrm{KOH} / \mathrm{g})$ & 50 & 160 \\
Copper Strip Corrosion $(3$ & 0.15 & 0.22 \\
$\left.\mathrm{~h} 50^{\circ} \mathrm{C}\right)$ & No $1 \mathrm{~A}$ & No $1 \mathrm{~A}$ \\
Sulfur content & 0.154 & 0 \\
Ash content $(\%)$ & 0.013 & 0.016 \\
Calorific value $(\mathrm{MJ} / \mathrm{kg})$ & 43 & 37.5 \\
\hline
\end{tabular}

Morphological and tribological analyses of the piston rings were performed in this study. The piston rings of the test engine, which was subjected to long-term operation with two different fuels, were removed and cleaned with alcohol. Then, these piston rings were made ready for analysis. In order to examine the structure of the piston rings operating under different conditions at the end of the combustion event, and 2000x magnification SEM / EDX 
analyzes of the first and second piston rings were performed. The representation of the piston rings on the piston was given in Figure 2. SEM/EDX analyses were conducted at Sivas Cumhuriyet University Advanced Technology Research and Application Center (CÜTAM).

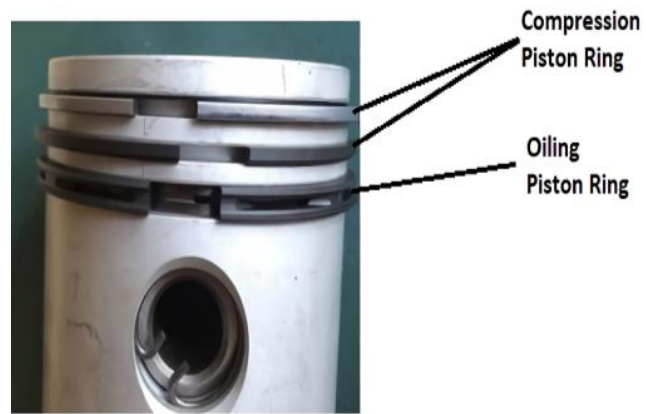

Figure 2. View of the piston rings on the piston

\section{Results and Discussions}

In addition to the effect of biodiesel fuels on engine parts, its effects on engine lubricating oil should also be known. In addition to the effect of biodiesel fuels on engine parts, a number of engine lubricating oil properties should also be known. Dynamic viscosity is a property of a fluid under the different forces. It is one of the most important parameters used to evaluate the condition of lubricating oil in engines. Viscosity plays an important role in the development and continuity of oil film thickness between two moving surfaces (piston ring and cylinder wall). As is known, the viscosity of biodiesel fuels is high compared to diesel fuel. When these results were examined, biodiesel fuel mixed with lubrication oil caused further dilution of the oil. As seen in Table 3, Viscosity of lubrication oil in COME10 fuelled engine is lower compared to the D100 fuel. This decrease is considered as an indication that biodiesel fuel cause to more dilution in engine lubrication oil.

Density is one of the most important features that distinguish liquids [23]. Increasing the density of oil reduces the mobility of the lubricant. On the other hand, if the density is too low, friction between moving parts increases, which can lead to more wear of engine components. Looking at the long-term endurance test results, it is seen that the lubricating oil density of COME10 blends fuel was slightly higher compared to D100 fuel. This is considered as an indication that biodiesel blended fuel is more involved in lubrication oil than diesel fuel. In particular, it is known biodiesel fuels have a higher density than diesel fuel. Table 4 shows the density and flash point values of engine oils that did not work and worked with two different fuels.

Table 3. The viscosity values of the lubricating oils under different operating conditions

\begin{tabular}{lcc}
\hline \multicolumn{1}{c}{ Fuel Type } & $\begin{array}{c}\text { Viscosity } \\
\left(\mathrm{mPa} . \mathrm{s}, 40{ }^{\circ} \mathrm{C}\right)\end{array}$ & $\begin{array}{c}\text { Viscosity } \\
\left(\mathrm{mPa} . \mathrm{s}, 100^{\circ} \mathrm{C}\right)\end{array}$ \\
\hline $\begin{array}{l}\text { Not working } \\
\text { Lubricating Oil }\end{array}$ & 267.1 & 46.2 \\
$\begin{array}{l}\text { Lubricating Oil } \\
\text { of D100 fuelled } \\
\text { engine }\end{array}$ & 180.1 & 39 \\
$\begin{array}{l}\text { Lubricating oil } \\
\text { of B10 fuelled } \\
\text { engine }\end{array}$ & 177.7 & 38.3 \\
\hline
\end{tabular}

Table 4. The viscosity values of the lubricating oils under different operating conditions

\begin{tabular}{lcc}
\hline \multicolumn{1}{c}{ Fuel Type } & $\begin{array}{c}\text { Density } \\
\left(\mathrm{kg} / \mathrm{m}^{3}, 15^{\circ} \mathrm{C}\right)\end{array}$ & Flash Point $\left({ }^{\circ} \mathrm{C}\right)$ \\
\hline $\begin{array}{l}\text { Not working } \\
\text { Lubricating Oil } \\
\text { Lubricating Oil } \\
\text { of D100 fuelled } \\
\text { engine }\end{array}$ & 863 & 42 \\
$\begin{array}{l}\text { Lubricating oil } \\
\text { of B10 fuelled } \\
\text { engine }\end{array}$ & 867.8 & 218 \\
\hline
\end{tabular}

Generally, flash point of oil should be higher to reduce the volatility structure. The height of flash point of lubricating oil indicates that it is higher of Van der Waals forces and thus increases the energy needed to vaporize the oil [23]. The decrease in flash point of lubrication oil is an indication that the oil is deteriorating. In particular, the volatility of fuels is thought to be an important factor here. This result supported both density and viscosity results.

The SEM/EDX image of the first piston ring of the engine before the 150-hour long-term endurance test (Figure 3) and after the test with COME10 fuel can be seen in Figure 4. When the atomic element distribution on the piston ring surface was examined, close to $100 \% \mathrm{Cr}$ element was found. With the COME10 study, the wear, which was more prominent in the first piston ring, and abrasion wear lines developed parallel to the slip direction of the piston were found. The SEM/EDX image of the first piston ring of the engine, where 150 hours of long-term endurance tests were applied with D100 fuel, was given in Figure 5. As in the result obtained with COME10 fuel, in the D100 study, nearly $100 \% \mathrm{Cr}$ element was found in the atomic 
element distribution formed in the first piston ring. When the material distribution of the original first piston ring (compression) surface without any treatment was examined, $\mathrm{Cr}, \mathrm{Mn}$, $\mathrm{Al}$ elements were found predominantly. Weight distributions included $97 \% \mathrm{Cr}, 1.63 \% \mathrm{Mn}$ and $0.47 \% \mathrm{Al}$ elements in Figure 3. Atomic distributions were determined as $97 \%, 1.54 \%$ and $0.9 \%$, respectively.

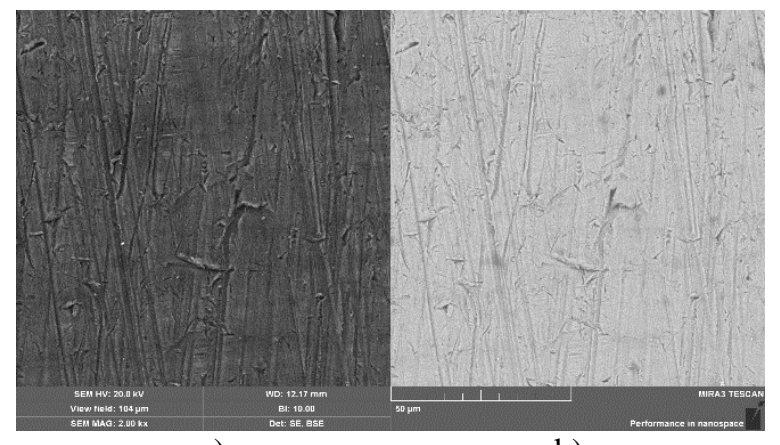

a)

b)

Figure 3. 2000x magnification SEM (a) and EDX (b) image of original first piston ring not worked

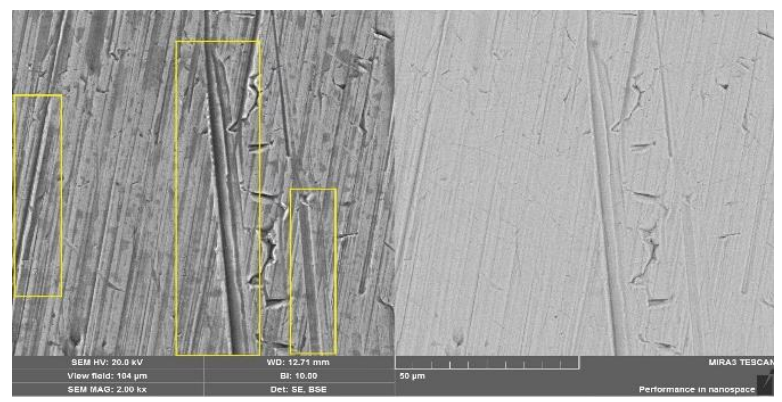

a)

b)

Figure 4. 2000x magnification SEM (a) and EDX (b) of the first piston ring at the end of operating with COME10 fuel.

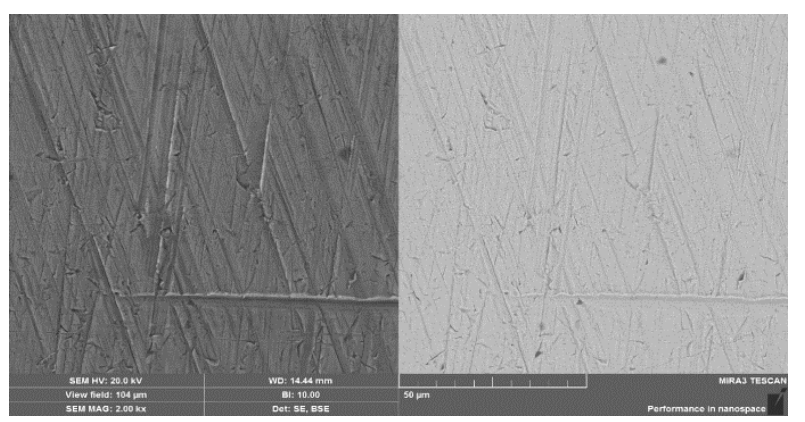

a)

b)

Figure 5. 2000x magnification SEM (a) and EDX (b) of the first piston ring at the end of operating with D100 fuel

In Figure 6 was given SEM and EDX images of the second piston ring (compression). As shown in Figure 7 and Figure 8, the surface morphology that occurs in the second piston ring was examined in two regions as a result of the study with COME10 fuel. However, as shown in Figure 9, single-zone SEM/EDX analysis was performed because the second piston ring surface of the engine using D100 fuel was considered more homogeneous than the COME10 study.

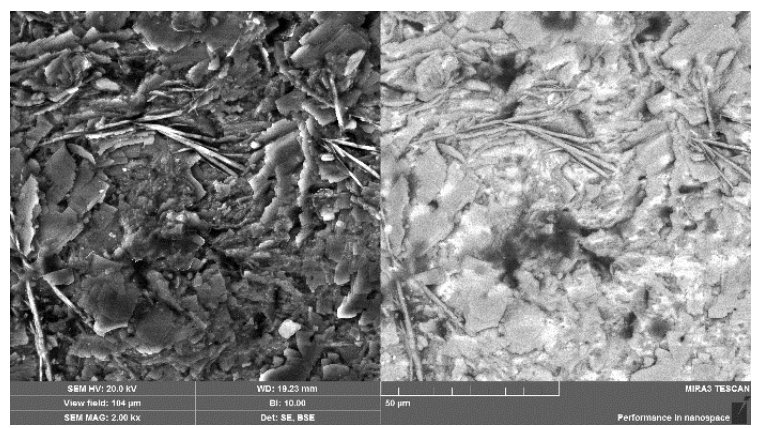

a)

b)

Figure 6. SEM (a) and EDX (b) image at 2000x magnification of the unworked second piston ring

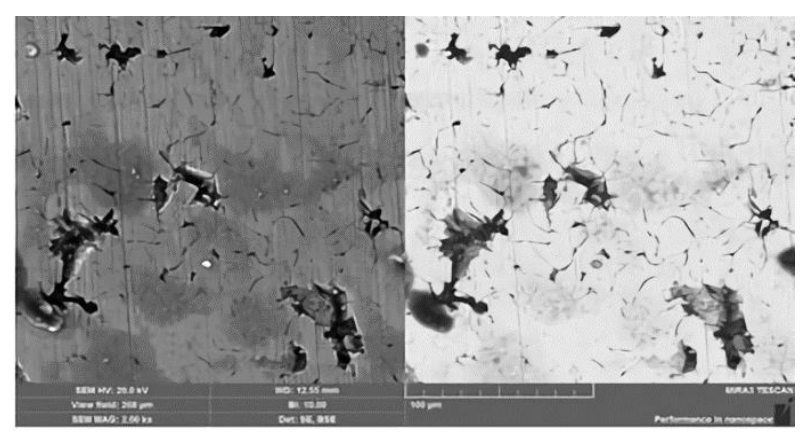

a)

b)

Figure 7. SEM (a) and EDX (b) images at 2000x magnification at the top of the second piston ring at the end of COME10 fuel operation.

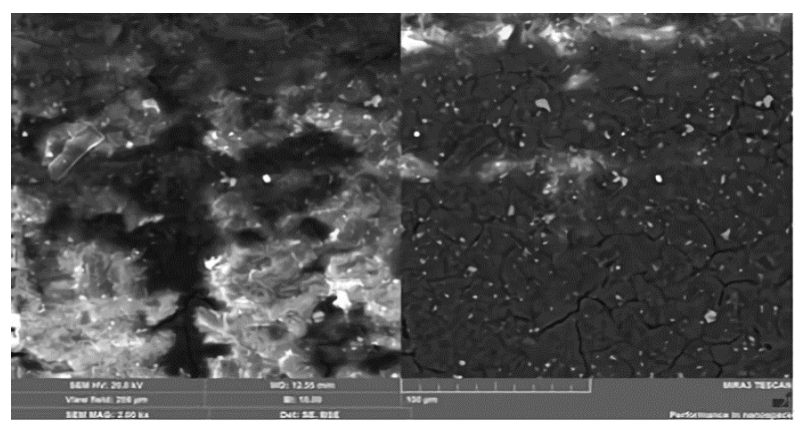

a)

b)

Figure 8. SEM (a) and EDX (b) images at 2000x magnification at the bottom of the second piston ring at the end of COME10 fuel operation

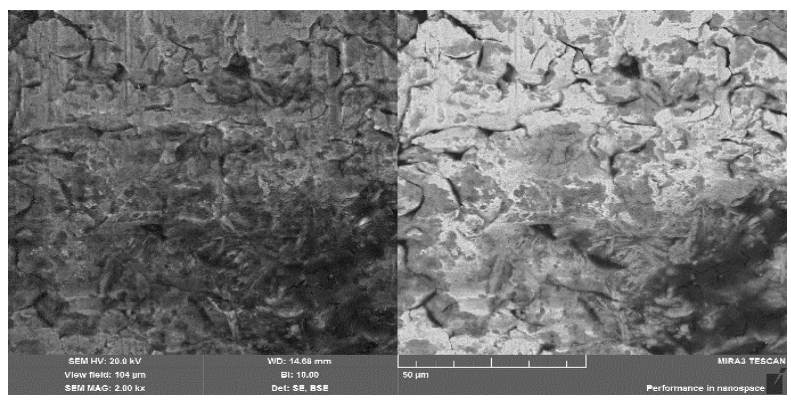

a)

b)

Figure 9. SEM (a) and EDX (b) images of the second piston ring at 2000x magnification as a result of operating with the D100 fuel 
D100 fuel produced less carbon on the piston ring surface compared to COME10 fuel operation. When the surface distribution of the second piston ring in the COME10 fuel operation is examined, it is seen that the combustion and fuel chemistry in the engine are more effective on the surface. Temperature and wear factors are seen to be effective on the second piston ring surface, which is mainly composed of Fe. Looking at the element distributions on the entire surface of the original second piston ring, approximately $51 \% \mathrm{Fe}, 28 \%$ $\mathrm{Zn}, 18.1 \% \mathrm{P}, 1.1 \% \mathrm{Si}$ and $0.8 \% \mathrm{Cr}$ elements were found. However, as a result of the engine operating with COME10 fuel, there are $95 \% \mathrm{Fe}$, $3.84 \% \mathrm{Si}$ and $0.76 \% \mathrm{Mn}$ elements at the top section of piston ring. Unburned $\mathrm{C}$ atoms, which were thought to be formed as a result of the presence of fuel and lubrication oil between cylinder and piston ring in the middle part of the piston ring, were found. In this region, $34 \% \mathrm{C}$ element and $23 \% \mathrm{O}$ element was observed. The weighted average of $\mathrm{Fe}$ atoms is $31.34 \%$. It is observed that there are predominantly $\mathrm{C}$ atoms on the surface of the bottom of the piston ring. In this region, EDX element distribution was approximately $60 \% \mathrm{C}, 28 \% \mathrm{O}, 4.4 \mathrm{Fe} \% \mathrm{Zn}$, $1.7 \% \mathrm{P}, 0.8 \% \mathrm{~S}$. The percentage of element $\mathrm{C}$ has gradually increased from the top to the bottom of the piston ring. This increase is also an indicator of the presence of accumulated unburned fuel on the surface. In general, it could be said that the Fe element was found in the top part of the second piston ring and more $\mathrm{C}$ element on the bottom region of the piston ring. D100 fuel operation with a more homogeneous surface morphology compared to the second piston ring of the engine operating with COME10 fuel, approximately $30 \% \mathrm{C}, \% 20 \mathrm{O}$ and $33.34 \% \mathrm{Fe}$ were detected in the middle part of the piston ring.

SEM/EDX image of the third unworked piston ring in Figure 10, Figure 11 shows the SEM/EDX image of the third piston ring of the engine operated with COME10 fuel, and the SEM/EDX image of the third piston ring of the engine operated with D100 fuel was given in Figure 12. When EDX analysis of the original unworked third piston ring was performed, predominantly $51 \% \mathrm{Fe}$ was found, while $28.65 \%, 18.15 \%, 1.14 \%$ and $0.84 \% \mathrm{Zn}, \mathrm{P}, \mathrm{Si}$ and $\mathrm{Cr}$ were determined, respectively. As a result of both fuel studies, the material distribution on the surface yielded similar results. As a result of operating with COME10 fuel, $96.12 \% \mathrm{Fe}$ was obtained on the entire surface of the third piston ring and Si element was found predominantly on the remaining part. On the other hand, $96.93 \% \mathrm{Fe}$ was found on the entire surface of the third piston ring operating with D100 fuel and Si was remained on the remaining part.

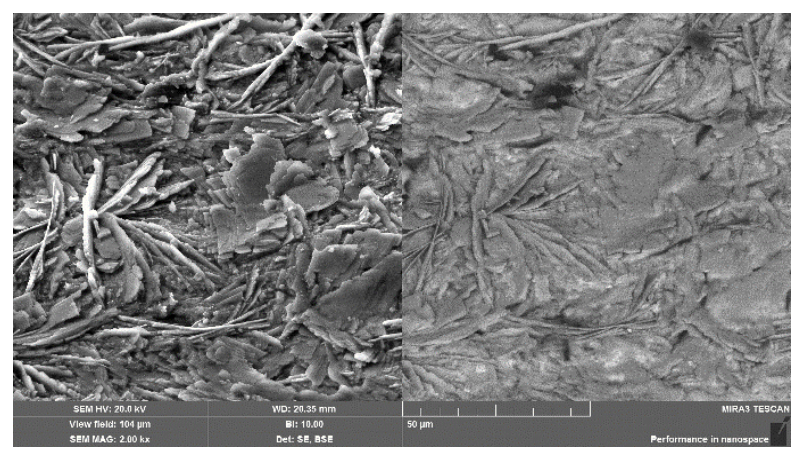

a)

b)

Figure 10. SEM (a) and EDX (b) images at 2000x magnification of the third unworked piston ring.

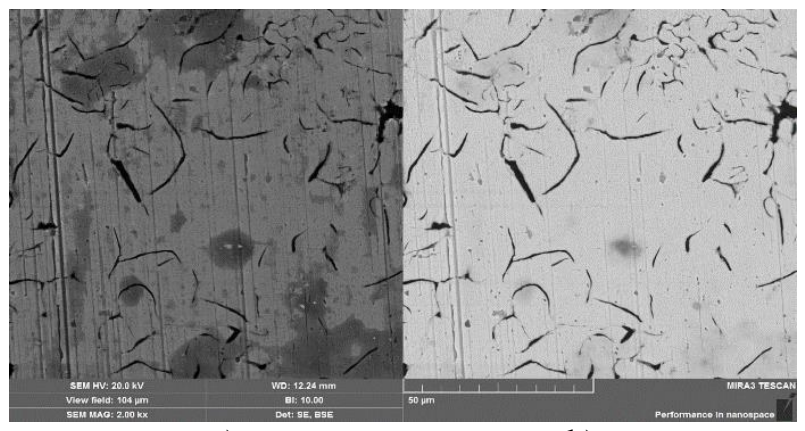

a)

b)

Figure 11. SEM (a) and EDX (b) images at 2000x magnification of the third piston ring as a result of operating with COME10 fuel

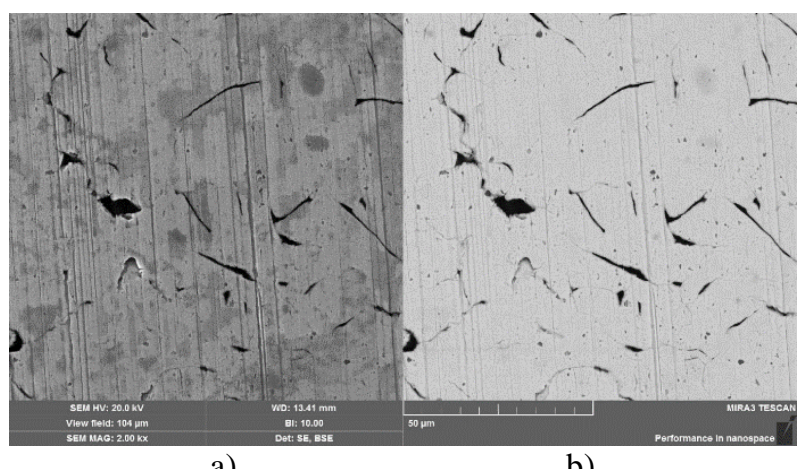

a)

b)

Figure 12. SEM (a) and EDX (b) images at 2000x magnification of the third piston ring as a result of operating with D100 fuel

\section{Conclusions}

Single cylinder, four-stroke and direct injection a diesel engine was used. The engine was 
operated with a mixture of $10 \%$ canola oil methyl ester $+90 \%$ diesel fuel (COME10) and diesel fuel. The engine was operated with both fuels at $1500 \mathrm{rpm}$ and part load. The engine was operated for 150 hours under these conditions and subjected to a long-term endurance test.

Naturally, the lubrication oil viscosity of the engine used different fuels has decreased over time compared to non-worked oil. When the density, viscosity and flash point values are examined, it can be said that biodiesel fuel is mixed more at lubricating oil compared to diesel fuel. Although deformation in lubricating oil is more in biodiesel fueled operation, this did not have a negative effect on wear. When the three most important features that give information about the quality of the lubricating oil are examined, it can also be said that, in the engine used biodiesel and diesel fuel, there was no significant change in the properties of the oil. The purpose of this study is; the surface structure was examined by taking SEM and EDX images before and after the operation in the three piston rings on the piston. Thus, the effect of diesel and biodiesel fuels on the piston ring surfaces was examined. As a result, 97\% $\mathrm{Cr}, 1,63 \% \mathrm{Mn}$ and $0,47 \% \mathrm{Al}$ elements were found in the weight distribution in the unworked first piston ring surface structure. After operating the engine with both fuels, $\mathrm{Cr}$ element was largely found in the first piston ring surface structure. It was observed that the structure did not deteriorate in the piston ring. However, wear which is more prominent in the first piston ring with canola oil methyl ester mixed fuel, and abrasion wear lines developing parallel to the sliding direction of the piston were found. Looking at the element distributions on the surface of the original second piston ring, approximately $51 \% \mathrm{Fe}, 28 \% \mathrm{Zn}, 18.1 \% \mathrm{P}, 1.1 \%$ $\mathrm{Si}$ and $0.8 \% \mathrm{Cr}$ elements were found.

D100 fuel compared to COME10 fuel, less carbon has formed on the surface of the piston ring. When the surface distribution of the second piston ring in the COME10 fuel operation is examined, it is seen that the combustion and fuel chemistry in the engine are more effective on the surface. Looking at the EDX analysis results of the unworked third piston ring, mainly $51 \% \mathrm{Fe}$, $28.65 \% \mathrm{Zn}, 18.15 \% \mathrm{P}, 1.14 \% \mathrm{Si}$ and $0.84 \% \mathrm{Cr}$ were detected. As a result of the engine running with COME 10 and diesel fuel, the third piston ring morphology is close to each other and it is Fe weighted.

\section{References}

1. Subhash, L.; Subramanian, K. Effect of different percentages of biodiesel-diesel blends on injection, spray, combustion, performance, and emission characteristics of a diesel engine, Fuel,139, 537-545, 2015.

2. Labeckas G.; Slavinskas, S.; Mazeika.; M. The effect of ethanoldiesel-biodiesel blends on combustion, performance and emissions of a direct injection diesel engine. Energy Conversion and Management, 79, 698-720, 2014.

3. Qi, D. H.; Chen, H.; Geng, L. M.; Bian, Y. Z. H.; Ren, X. C. H.; Performance and combustion characteristics of biodiesel-dieselmethanol blend fuelled engine, Applied Energy, 87, 5, 1679-1686, 2010.

4. Cesur, İ. Investigation of the effect of the different fuel mixtures on the properties of friction and wear between cylinder liner surface - piston ring, Sakarya University, Institute of Science and Technology, Master's thesis, Sakarya, Turkey, 2008.

5. Sinha, S.; Agarwal, A. K. Experimental investigation of the effect of biodiesel utilization on lubricating oil degradation and wear of a transportation CIDI engine, Journal of Engineering for Gas Turbines and Power,132, 4, 1-9, 2010.

6. Hisham, S.; Kadirgama, K.; Ramasamy, D.; Noor, M. M.; Amirruddin, A. K.; Najafi, G.; Rahman, M. M. Waste cooking oil blended with the engine oil for reduction of friction and wear on piston skirt, Fuel, 205, 247-261, 2017.

7. Srivastava, D. K.; Agarwal, A. K.; Kumar, J. Effect of liner surface properties on wear and friction in a non-firing engine simulator, Materials and Design, 28, 5, 16321640, 2007.

8. Andersson, P. Piston ring tribology, VTT Industrial Systems, Research Notes 2178, Finland, 20-22, 2002.

9. Temizer, İ.; Cihan, Ö. Dizel ve biyodizel/dizel karışımlı yakıtların segman yüzey yapıs1 üzerindeki etkisinin incelenmesi, 4. International Conference on Material Science and Technology (IMSTEC), 18-20 October 2019, Ankara, Turkey.

10. Liao, K.; Liu, Y.; Kim, D.; Urzua, P.; 
Tian, T.; Practical challenges in determining piston ring friction, Journal of Engineering Tribology, 227, 2, 112- 125, 2012.

11. Dhar, A.; Agarwal, A. K. Experimental investigations of effect of Karanja biodiesel on tribological properties of lubricating oil in a compression ignition engine, Fuel, 130, 112119, 2014.

12. Pandey, A. K.; Nandgaonkar, $M$. Experimental investigation of the effect of esterified karanja oil biodiesel on lubricating oil and wear of a $780 \mathrm{hp}$ military CIDI engine, SAE International Journal of Fuels and Lubricants, 3, 2, 273-279, 2010.

13. Gopal, K. N.; Thundil, R.; Raj, K. Effect of pongamia oil methyl ester-diesel blend on lubricating oil degradation of DI compression ignition engine, Fuel,165, 105-114, 2016.

14. Agarwal, A. K.; Bijwe, J.; Das, L. M. Wear assessment in a biodiesel fueled compression ignition engine. Journal of Engineering for Gas Turbines and Power, 125, 3, 820-826, 2003.

15. Agarwal, A. K.; Srivastava, D. K.; Dwivedi, D.; Kawatra, G.; Kumer, M. R.; Bhardwaj, O. P.; Abraham, M.; Jaura, A. Field trial of biodiesel (B100) and diesel fuelled common rail direct injection Euro-III compliant sports utility vehicles in India condition. SAE Paper, 28-0077, 537-543, 2008.

16. Agarwal, A. K.; Dhar, A. Karanja oil utilization in DI engine by preheating: experimental investigations of engine durability and lubricating oil properties, Proceedings of the Institution of Mechanical Engineers Part D Journal of Automobile Engineering, 224, 1, 8597, 2009.

17. Gulzar, M.; Effects of biodiesel blends on lubricating oil degradation and piston assembly energy losses, Energy, 111, 713-721, 2016.

18. Kalam, M. A.; Masjuki, H. H.; Mohamad E. N. Wear and lubrication characteristics of a multi-cylinder diesel engine using vegetable oil blended fuel, World Tribology Congress III, 12-16 Sept 2005, Washington, USA.

19. Gökalp, B.; Saraç, İ.; Çelik, C. Destruction analysis depend on the wearing with oil analysis program, In: Proceedings of 8th International Fracture Conference, 7-9 Nov 2007, Istanbul, Turkey.
20. Balc1, A. B.; Investigation for effects of bioethanol and terebinth biodiesel blends with diesel to performance, exhaust emissions and lubricating oil in diesel engine, Selçuk University, Institute of Science and Technology, Doctoral thesis, Konya, Turkey, 2017.

21. Aydin, F.; Effects of using E-B diesel fuel in single cylinder diesel engine to engine performance, emissions and lubrication oil, Selçuk University, Institute of Science and Technology, Doctoral thesis, Konya, Turkey, 2014.

22. Elkelawya, M.; Bastawissia, H. A.; Esmaeila, K. K.; Radwana, A. M.; Panchalb, H.; Sadasivunic, K. K.; Ponnammac, D.; Walvekard, R. Experimental studies on the biodiesel production parameters optimization of sunflower and soybean oil mixture and DI engine combustion, performance, and emission analysis fueled with diesel/biodiesel blends, Fuel, 255, 1-12, 2019.

23. Temizer, İ; The combustion analysis and wear effect of biodiesel fuel used in a diesel engine, Fuel, 117571, 270, 2020. 